\title{
Translational Cancer Research (TCR) is going to publish monthly starting in September 2019!
}

\author{
Editorial Office \\ AME Publishing Company \\ Correspondence to: Editorial Office. AME Publishing Company. Email: tcr@amepc.org.
}

Submitted Sep 10, 2019. Accepted for publication Sep 11, 2019.

doi: $10.21037 /$ tcr.2019.09.31

View this article at: http://dx.doi.org/10.21037/tcr.2019.09.31

Since its launch in 2012, Translational Cancer Research (TCR) has been published bi-monthly with both online and printed copies. From year to year, the submissions to TCR has been rapidly increasing. This is a reflection of the ever-increasing recognition of TCR and continuing support by our authors. As a high-quality academic exchange platform, we would like to assist more and more clinicians and researchers in showcasing their scientific achievements. We are also committed to publishing articles quickly, allowing for impactful and potentially practicechanging articles to be available to readers soon after acceptance. Therefore, we are delighted to inform you that the TCR will be a monthly publication beginning in September 2019.

TCR is now indexed in Science Citation Index Expanded (SCIE) and Scopus. We welcome all manuscripts on laboratory studies of novel therapeutic interventions, clinical trials which evaluate new treatment paradigms for cancer, results of novel research investigations which bridge the laboratory and clinical settings including risk assessment, cellular and molecular characterization, prevention, detection, diagnosis and treatment of human cancers with the overall goal of improving the clinical care of cancer patients and etc. There are also nine focused issues mentioned below that will be featured in future journal issues.

\section{Focused issues in preparation}

(I) Rare Tumors of the Breast (link: http://tcr.amegroups.com/ post/view/focused-issue-on-rare-tumors-of-the-breast)

(II) Recent Developments in Benign Tracheal Stenosis (link: http://tcr.amegroups.com/post/view/focused-issue-onrecent-developments-in-benign-tracheal-stenosis)

(III) Radiotherapy for Breast Cancer in Advanced Age (link: http://tcr.amegroups.com/post/view/focused-issue-onradiotherapy-for-breast-cancer-in-advanced-age)

(IV) Oral Pre-cancer and Cancer (link: http://tcr.amegroups. $\mathrm{com} /$ post/view/focused-issue-on-oral-pre-cancer-andcancer)

(V) Tumor Immune Microenvironment in Cancer Progression and Cancer Therapy (link: http://tcr.amegroups. com/post/view/focused-issue-on-tumor-immune- microenvironment-in-cancer-progression-and-cancertherapy)

(VI) Energy Balance, Aging, Obesity, and Cancer (link: http:// tcr.amegroups.com/post/view/focused-issue-on-energybalance-aging-obesity-and-cancer)

(VII) Prostate Cancer (link: http://tcr.amegroups.com/post/ view/focused-issue-on-prostate-cancer)

(VIII) Loco-regional Therapy for Metastatic Breast Cancer (link: http://tcr.amegroups.com/post/view/focused-issue-on-locoregional-therapy-for-metastatic-breast-cancer)

(IX) Urothelial Carcinoma (link: http://tcr.amegroups.com/ post/view/focused-issue-on-urothelial-carcinoma)

\section{Acknowledgments}

Funding: None.

\section{Footnote}

Provenance and Peer Review: This article was commissioned by the editorial office, Translational Cancer Research. This article did not undergo external peer review.

Conflicts of Interest: The authors have no conflicts of interest to declare.

Open Access Statement: This is an Open Access article distributed in accordance with the Creative Commons AttributionNonCommercial-NoDerivs 4.0 International License (CC BYNC-ND 4.0), which permits the non-commercial replication and distribution of the article with the strict proviso that no changes or edits are made and the original work is properly cited (including links to both the formal publication through the relevant DOI and the license). See: https://creativecommons.org/licenses/by-nc-nd/4.0/.

Cite this article as: Editorial Office. Translational Cancer Research (TCR) is going to publish monthly starting in September 2019! Transl Cancer Res 2019;8(5):1655. doi: 10.21037/tcr.2019.09.31 